\title{
Pertumbuhan dan Hasil Tanaman Cabai (Capsicum annuum L.) Akibat Perbedaan Jenis Media Tanam dan Varietas Secara Hidroponik Substrat
}

\section{Growth and yield of paper (Capsicum annuum L.) due to differences in the type of planting media and varieties in hydroponic substrates}

\author{
Riska Andani ${ }^{1}$, Marai Rahmawati ${ }^{1}$, Mardhiah Hayati ${ }^{1 *}$ \\ ${ }^{1}$ Program Studi Agroteknologi, Fakultas Pertanian, Universitas Syiah Kuala \\ *Corresponding author:mardhiah_h@unsyiah.ac.id
}

\begin{abstract}
Abstrak. Penelitian ini bertujuan untuk mengetahui pengaruh jenis media tanam dan varietas serta interaksi antara keduanya terhadap pertumbuhan dan hasil tanaman cabai merah yang ditanam dengan metode hidroponik substrat. Penelitian ini dilaksanakan di Rumah Kasa dan Laboratorium Hortikultura Fakultas Pertanian Universitas Syiah Kuala dari April sampai Agustus 2019. Penelitian ini menggunakan Rancangan Acak Kelompok pola faktorial $3 \times 3$ dengan 3 ulangan, sehingga terdapat 9 kombinasi perlakuan. Faktor yang diteliti yaitu jenis media tanam yang terdiri dari 3 taraf (arang sekam, petroganik + pasir, petroganik + arang sekam) dan varietas yang terdiri dari 3 taraf (Kencana, Laba dan Lado F1). Parameter yang diamati ialah tinggi tanaman dan diameter batang pada umur 14, 21, 28, 35, 42, 29 dan 56 HST, umur tanaman saat berbunga, umur panen, panjang buah, jumlah buah, berat buah per buah, berat buah per tanaman sebanyak 7 kali pemanenan dan potensi hasil. Hasil penelitian menunjukkan bahwa jenis media tanam berpengaruh sangat nyata terhadap tinggi tanaman cabai pada umur 14, 21, 28, 35 dan 56 HST, diameter batang pada umur 21, 35, 42 dan 56 HST, panjang buah serta berpengaruh nyata terhadap tinggi tanaman cabai pada umur 42 dan 49 HST, diameter batang pada umur 14 dan 28 HST. Pertumbuhan tanaman cabai yang terbaik dijumpai pada jenis media tanam petroganik + arang sekam. Pertumbuhan tanaman cabai yang terbaik dijumpai pada varietas Kencana. Interaksi antara jenis media tanam dan varietas berpengaruh tidak nyata terhadap semua peubah pertumbuhan dan hasil tanaman yang diamati.
\end{abstract}

Kata kunci : Substrat, Hidroponik, Arang sekam, Pasir, Petroganik, Potensi Hasil

\begin{abstract}
This study aims to determine the effect of planting media types and varieties and the interaction between two treatments to the growth and yield of red chili plants which were planted in substrates hydroponics. The research was conducted at the Greenhouse and Laboratory of Agriculture, Faculty of Agriculture, Syiah Kuala University from April until September 2019.The study designed as a factorial randomized block design of $3 \times 3$ with 3 replications, thus there were 9 treatment combinations. The factors observed were the planting media types consisted of 3 levels (husk charcoal, petroganik + sand and husk + petroganic charcoal) and varieties consisted of 3 levels (Kencana, Laba F1 and Lado F1). The parameters observed were plant height and stem diameter at 14, 21, 28, 35, 42, 49 and 56 DAP, the first flowering age, the first harvesting age, fruit length, number of fruits, each fruit weight, fruit weight per plant during 7 times harvesting and potential yield. The results indicates that the types of planting media had a very significant effect on the height of chilli plants 14,21 , 28, 35 and 56 DAP, stem diameter at 21,35, 42 and 56 DAP, fruit length and significantly affected the plant height at 42 and 49 DAP, and stem diameter at 14 and 28 DAP. The best plant growth was found in the type of rice husk charcoal + Petroganik. Varieties significantly affected the plant height at 56 DAP. The best growth of chili plants was found in the F1 Laba and Lado F1 varieties. The results indicated that there was an interaction between the planting media types and varieties of chilli plants that had no significant effect on all growth parameters and yield of the plants.
\end{abstract}

Keywords: Substrates, Hydroponics, Husk Charcoal, Sand, Petroganik, Potential Yield

\section{PENDAHULUAN}

Cabai merah (Capsicum annuum L.) merupakan tanaman hortikultura yang termasuk dalam famili Solanaceae. Cabai merah memiliki nilai ekonomi serta nutrisi yang tinggi. Kandungan gizi yang terdapat pada tanaman cabai merah seperti protein, lemak, karbohidrat, kalsium, vit (A dan C) menjadikan cabai merah sebagai komoditi yang dibutuhkan masyarakat untuk bahan masakan (Rindani, 2015). Cabai merah sangat populer di indonesia 
karena memiliki rasa yang pedas juga mempunyai kandungan gizi yang baik (Fahmi dan Sujitno, 2011). Dalam $100 \mathrm{~g}$ buah cabai terkandung 90,9 \% kadar air, 31 kalori, $1 \mathrm{~g}$ protein, 0,3 g lemak, 7,3 g karbohidrat, $29 \mathrm{mg}$ kalsium, $24 \mathrm{mg}$ fosfor, $47 \mathrm{mg}$ vit A dan $18 \mathrm{mg}$ vit C (Sutrisni, 2016).

Produksi cabai merah di Indonesia mengalami fluktuasi selama lima tahun terakhir, pada tahun 2013 produksi cabai merrah menjadi 1,01 juta ton, lalu mengalami peningkatan menjadi 1,07 juta ton pada tahun 2014, namun pada tahun 2015 dan 2016 mengalami penurunan ,menjadi 1,04 juta ton dan pada tahun 2017 produksi cabai merah mengalami peningkatan menjadi 1,20 juta ton. Produksi cabai merah di Aceh pada tahun 2017 hanya 53,041 ribu ton (Kementrian Pertanian Republik Indonesia, 2018). Konsumsi cabai merah akan terus meningkat dari tahun ke tahun karena meningkatnya jumlah penduduk.

Penurunan mutu dan produksi cabai merah yang tidak stabil disebabkan oleh cuaca yang tidak menentu, serangan hama, penyakit, virus dan cendawan. Oleh karena itu budidaya tanaman cabai merah membutuhkan perawatan yang optimal dan kondisi lingkungan yang tepat (Suwardani et al., 2014). Salah satu upaya untuk meningkatkan produksi cabai merah yang berkualitas iialah dengan cara budidaya cabai merah secara hidroponik substrat. Teknik budidaya hidroponik mampu meningkatkan hasil produksi tanaman bila dibandingkan dengan teknik budidaya konvensional (Indrawati et al., 2012).

Hidroponik yaitu salah satu cara budidaya tanaman tanpa menggunakan tanah, biasanya menggunakan media arang sekam, pasir, serta serbuk kelapa (cocopeat). Adapun faktor-faktor yang terdapat pada sistem hidroponik yaitu suhu, ketersediaan air dan kelembaban yang dapat diatur (Purnomo et al., 2016). Keuntungan dari sestem hidroponik adalah menghemat luasan lahan, memudahkan dalam penanganan gulma, serangan hama penyakit, mudah dalam penyiraman, kualitas produk yang dihasilkan baik, menghemat penggunaan pupuk dan mendapatkan hasil panen yang lebih besar (Siswandi, 2006). Sistem hidroponik mempunyai beberapa kelemahan ialah perlu keterampilan yang baik untuk membuat racikan bahan kimia, ketersediaannya dan pemeliharaan perangkat hidroponik susah (Istiqamah, 2006).

Sistem hidroponik dapat dikelompokkan menjadi dua yaitu kultur substrat dan kultur larutan nutrisi. Kultur substrat merupakan suatu media tanpa menggunakan tanah, namun dapat menggunakan media padat lain seperti arang sekam, pasir, petroganik dan cocopeat yang yang dapat dijadikan pada tanaman tersebut tumbuh dan berkembang seperti halnya menggunakan media tanah sedangkan kultur larutan nutrisi yaitu media yang menggunakan media air yang sudah disediakan hidroponik sistem rakit apung (Subandi et al., 2015; Onggo et al., 2017).

Arang sekam merupakan salah satu media yang dapat digunakan untuk budidaya secara hidroponik. Arang sekam mudah diperoleh dan harganya relatif murah. Pasir merupakan media tanam yang digunakan sebagai pengganti tanah. Pasir juga memiliki pori-pori yang berukuran besar (makro) dan sebagai bahan organik yang mempunyai sifat menahan air untuk memperbaiki sifat tanah (Putra et al. 2013). Selain pasir bahan organik yang bisa digunakan sebagai media hidroponik adalah petroganik yang dijadikan sebagai media tanam campuran. Petroganik merupakan bahan campuran yang sudah diolah menjadi efektif dan efisien (Sulistio et al., 2018). Bahan penyusun petroganik yaitu pupuk kandang dari kotoran sapi, limbah pabrik gula, limbah pabrik sawit (tandan kosong), kapur atau tanah liat. Petroganik juga memiliki kandungan yaitu C-organik 15\%, pH 4-9, berbentuk butiran, bebas patogen dan gulma serta kadar air 8-20\% (Siswanto dan Widowati, 2017). Kegunaan petroganik juga dapat menggemburkan dan menyuburkan tanah untuk memperkaya hara makro dan mikro sesuai dengan jenis tanah dan tanaman (Hijrah et al., 2017). Untuk meningkatkan produksi tanaman 
selain jenis media tanam diperlukan juga penggunaan varietas unggul yang memiliki potensi hasil yang tinggi.

Salah satu varietas cabai unggul yaitu varietas Kencana. Varietas cabai merah Kencana memiliki beberapa keunggulan yaitu potensi hasil produksi mencapai 18,4 ton ha ${ }^{-1}$ dan jumlah buah mencapai 1000 buah per tanaman. Varietas unggul lainnya yaitu varietas cabai merah Laba F1 memiliki keunggulan yaitu dapat tumbuh di daerah dataran rendah sampai dataran tinggi, tahan terhadap penyakit busuk akar dan layu bakteri. Varietas cabai merah Lado F1 memiliki banyak keunggulan yaitu tahan terhadap beberapa penyakit layu fusarium dan tahan terhadap hama seperti ulat daun, wereng dan walang sangit. Cabai merah varietas Lado F1 ini dapat menghasilkan buah yang lebih banyak dan menguntungkan dari pada varietas lain serta memiliki umur panen 115-120 HST (Prakosa, 2000).

Tujuan penelitian untuk mengetahui pengaruh jenis media tanam dan varietas serta interaksi antara keduanya terhadap pertumbuhan dan hasil tanaman cabai secara hidroponik substrat.

\section{METODE PENELITIAN}

Penelitian ini dikerjakan di Rumah Kasa dan Laboratorium Hortikultura Fakultas Pertanian Universitas Syiah Kuala, Banda Aceh.

\section{MATERI DAN METODE}

\section{Alat dan Bahan}

Alat yang digunakan ialah tray, timbangan digital, meteran, gelas ukur, Total Dissolve Solid (TDS), pH meter, jangka sorong. Bahan yang digunakan dalam penelitian ini ialah benih cabai varietas Kencana, Laba F1 dan Lado F1 masing-masing sebanyak 150 benih, $1 \mathrm{~kg}$ pupuk AB MIX, $122 \mathrm{~kg}$ arang sekam, $140 \mathrm{~kg}$ petroganik, $60 \mathrm{~kg}$ pasir, insektisida pegasus dan 81 polibag berukuran $30 \times 40 \mathrm{~cm}(5 \mathrm{~kg})$.

\section{Rancangan dan Pelaksanaan Penelitian}

Penelitian ini menggunakan Rancangan Acak Kelompok (RAK) pola faktorial 3 x 3 dengan 3 ulangan yang terdiri dari 2 faktor yaitu jenis media tanam dan varietas dengan 3 taraf sehingga diperoleh 9 kombinasi perlakuan dan 27 unit percobaan, setiap percobaan terdiri dari 3 unit sehingga diperoleh 81 tanaman. Data dianalisi dengan menggunakan uji $\mathrm{F}$, UNTUK mengetahui pengaruh perlakuan apabila perlakuan berpengaruh nyata, maka dilakukan analisis uji lanjut dengan menggunakan uji Beda Nyata Jujur pada taraf $5 \%$ (BNJ $0,05)$.

Pelaksanaan penelitian ini terlebih dahulu dilakukan persiapan benih satu hari sebelum tanam. Benih direndam selama 24 jam agar mendapatkan benih yang baik. Selanjutnya disemai di dalam tray menggunakan media arang sekam, benih diisi 1 benih per lubang tanam dan disiram setiap dua minggu sekali, disiram menggunakan pupuk urea sebanyak $20 \mathrm{ml}$ dalam $10 \mathrm{~g}$ per liter air sampai benih berumur 21 hari, Lalu bibit tersebut dipindahkan ke dalam polibag. Pembuatan larutan nutrisi yang dibutuhkan selama 30 hari diberikan pada tanaman sebanyak $100 \mathrm{ml}$ per tanaman pada pagi hari. Selanjutnya persiapan media tanam dilakukan dengan menyiapkan media arang sekam, petroganik + pasir (2:1), petroganik + arang sekam (1:1) ke dalam polibag ukuran 30 x $40 \mathrm{~cm}(5 \mathrm{~kg})$. Selanjutnya setelah bibit berumur $30 \mathrm{HST}$, lalu dipindahkan ke dalam polibag yang sudah disiapkan dan disiram pada sore hari. Pemeliharaan tanaman cabai merah terdiri dari penyiraman, penyulaman, 
pengendalian hama dan penyakit, pemasangan ajir dan pemangkasan pada tanaman cabai merah. Pemanenan dilakukan pada saat cabai merah varietas Kencana berumur 95 HST, Laba F1 berumur 90 HST dan Lado F1 berumur 115 HST dengan kriteria cabai merah yang sudah siap panen.

\section{Parameter Penelitian}

Peubah yang digunakan ialah tinggi tanaman dan diameter batang umur 14, 21, 28, 35, 42, 49 dan 56 HST, umur tanaman saat berbunga, umur panen, panjang buah, jumlah buah, berat buah per buah, berat buah per tanaman dan potensi hasil.

Potensi hasil $\left(\right.$ ton $\left.\mathrm{ha}^{-1}\right)=$ Luas Lahan 1 ha- $20 \% \mathrm{x}$ Berat buah per tanaman

\section{HASIL DAN PEMBAHASAN}

\section{Pengaruh Jenis Media Tanam terhadap Pertumbuhan dan Hasil Tanaman Cabai Merah Secara Hidroponik Substrat}

Hasil uji F (Tabel Lampiran 1) menunjukkan bahwa jenis media tanam berpengaruh sangat nyata terhadap tinggi tanaman cabai pada umur 14, 21, 28, 35 dan 56 HST, diameter batang pada umur 21, 35, 42 dan 56 HST dan panjang buah serta berpengaruh nyata terhadap tinggi tanaman cabai pada umur 42 dan 49 HST, diameter batang pada umur 14 dan 28 HST dan berat buah per buah, namun tidak berpengaruh nyata terhadap diameter batang pada umur 49 HST, umur tanaman saat berbunga, umur panen, jumlah buah, berat buah per tanaman dan potensi hasil. Rata-rata pertumbuhan tanaman cabai merah akibat perlakuan jenis media tanam dapat dilihat pada Tabel 1.

Tabel 1. Rata-rata tinggi tanaman dan diameter batang cabai merah akibat perlakuan jenis media tanam secara hidroponik substrat

\begin{tabular}{|c|c|c|c|c|c|}
\hline \multirow{2}{*}{\multicolumn{2}{|c|}{ Peubah yang diamati }} & \multicolumn{3}{|c|}{ Jenis Media Tanam } & \multirow[b]{2}{*}{$\mathrm{BNJ}_{0,05}$} \\
\hline & & $\mathrm{M}_{1}$ & $\mathrm{M}_{2}$ & $\mathrm{M}_{3}$ & \\
\hline \multirow{7}{*}{ Tinggi tanaman $(\mathrm{cm})$} & $14 \mathrm{HST}$ & $8,28 \mathrm{a}$ & $8,32 \mathrm{a}$ & $12,75 \mathrm{~b}$ & 2,62 \\
\hline & $21 \mathrm{HST}$ & $10,63 \mathrm{a}$ & $12,62 \mathrm{a}$ & $16,42 \mathrm{~b}$ & 3,21 \\
\hline & $28 \mathrm{HST}$ & $13,38 \mathrm{a}$ & $17,62 \mathrm{ab}$ & $19,95 \mathrm{~b}$ & 3,83 \\
\hline & 35 HST & $16,40 \mathrm{a}$ & $21,87 \mathrm{~b}$ & $22,71 \mathrm{~b}$ & 4,52 \\
\hline & $42 \mathrm{HST}$ & $20,74 \mathrm{a}$ & $24,51 \mathrm{ab}$ & $25,84 \mathrm{~b}$ & 4,70 \\
\hline & 49 HST & $23,98 \mathrm{a}$ & $27,84 \mathrm{ab}$ & $29,58 \mathrm{~b}$ & 5,36 \\
\hline & $56 \mathrm{HST}$ & $29,04 \mathrm{a}$ & $38,16 \mathrm{~b}$ & $38,64 \mathrm{~b}$ & 7,55 \\
\hline \multirow{7}{*}{ Diameter batang (mm) } & 14 HST & $1,22 \mathrm{a}$ & $1,45 \mathrm{ab}$ & $1,75 \mathrm{~b}$ & 0,45 \\
\hline & $21 \mathrm{HST}$ & $1,75 \mathrm{a}$ & $2,19 \mathrm{ab}$ & $2,62 \mathrm{~b}$ & 0,40 \\
\hline & $28 \mathrm{HST}$ & $1,91 \mathrm{a}$ & $2,44 a b$ & $2,77 \mathrm{~b}$ & 0,69 \\
\hline & 35 HST & $2,08 \mathrm{a}$ & $2,87 \mathrm{a}$ & $2,98 \mathrm{~b}$ & 2,22 \\
\hline & $42 \mathrm{HST}$ & $3,13 \mathrm{a}$ & $3,46 \mathrm{a}$ & $4,28 \mathrm{a}$ & 1,38 \\
\hline & 49 HST & 4,05 & 4,58 & 5,04 & \\
\hline & 56 HST & $4,51 \mathrm{a}$ & $4,87 \mathrm{ab}$ & $5,98 \mathrm{~b}$ & 1,11 \\
\hline
\end{tabular}

Keterangan: Angka yang diikuti oleh huruf yang sama pada kolom yang sama berbeda tidak nyata pada taraf $5 \%$ (Uji BNJ 0.05 ). 
Hasil penelitian menunjukkan bahwa tinggi tanaman cabai merah pada umur 14, 21, 28, 35, 42, 49 dan 56 HST, diameter batang umur 14, 21, 28, 35, 42 dan 56 HST terbaik dijumpai pada jenis media tanam petroganik + arang sekam. Hal ini karena C-Organik yang tinggi berasal dari petroganik + arang sekam yang memiliki kemampuan menyimpan air lebih lama karena media tanam arang sekam merupakan bahan organik yang mempunyai kemampuan porositas yang baik dan mampu mendukung struktur media.

Hasil penelitian menunjukkan bahwa jenis media tanam pada panjang buah serta berat buah per buah terbaik dijumpai pada jenis media tanam petroganik + arang sekam. Hal ini sejalan dengan penelitian Cendana (2016) bahwa jenis media arang sekam dapat mempengaruhi tinggi tanaman dan diameter batang sehingga baik dalam pertumbuhan tanaman cabai merah sedangkan petroganik mengandung C-Organik yang mempengaruhi tinggi tanaman dan diameter batang. Hal ini disebabkan karena C-Organik mampu membantu penyerapan unsur hara oleh akar tanaman sehingga pertumbuhan tanaman menjadi lebiih baik. Arang sekam memiliki beberapa kandungan yaitu $\mathrm{SiO}_{2} 52 \%$ dan $\mathrm{C} 31 \%$ yang dapat memperbaiki sifat fisik media (Isworo, 2018). Penunjang keberhasilan dari sistem budidaya hidroponik yaitu media yang bersifat poros dan aerasi baik serta nutrisi yang cukup untuk pertumbuhan tanaman (Perwitasari et al., 2012).

Potensi hasil cabai merah terendah dijumpai pada jenis media tanam arang sekam. Hal ini karena arang sekam mengandung unsur hara yang sedikit. Sejalan dengan penelitian Gustia (2013) bahwa arang sekam memiliki sifah poros dan kandungan air yang sedikit. Perbandingan antara media tanam arang sekam, petroganik + pasir dan petroganik + arang sekam ialah pada kemampuan menyimpan airnya.

Pertumbuhan tanaman cabai merah terbaik dijumpai pada petroganik + arang sekam sehingga memiliki kemampuan menyimpan air lebih lama sedangkan pada media tanam arang sekam dan petroganik + pasir memiliki kandungan C-Organiknya rendah.

Tabel 2. Rata-rata umur tanaman saat berbunga, umur panen, panjang buah, jumlah buah, berat buah per buah, berat buah per tanaman dan potensi hasil

\begin{tabular}{cllll}
\hline $\begin{array}{c}\text { Umur tanaman saat } \\
\text { berbunga }\end{array}$ & 64,74 & 65,96 & 70,44 & \\
\hline Umur panen & 89,00 & 91,44 & 88,33 & \\
\hline Panjang buah $(\mathrm{cm})$ & $6,62 \mathrm{a}$ & $8,53 \mathrm{~b}$ & $10,00 \mathrm{c}$ & 1,02 \\
\hline Jumlah buah per tanaman & 22,67 & 25,15 & 26,78 & \\
\hline Berat buah per buah (g) & $3,03 \mathrm{a}$ & $3,52 \mathrm{~b}$ & $3,54 \mathrm{~b}$ & 0,25 \\
\hline $\begin{array}{c}\text { Berat buah per tanaman } \\
\text { (g) }\end{array}$ & 49,57 & 59,37 & 56,56 & \\
\hline $\begin{array}{c}\text { Potensi hasil } \\
\text { (ton ha }{ }^{-1} \text { ) }\end{array}$ & 1,58 & 1,90 & 1,81 & \\
\hline Keterangan & & & & \\
\hline
\end{tabular}

Keterangan: Angka yang diikuti oleh huruf yang sama pada kolom yang sama berbeda tidak nyata pada taraf 5\% (Uji BNJ 0.05 ).

\section{Pengaruh Varietas terhadap Pertumbuhan dan Hasil Tanaman Cabai Merah Secara Hidroponik Substrat}

Hasil uji F (Tabel Lampiran 1) menunjukkan bahwa perlakuan varietas berpengaruh nyata terhadap tinggi tanaman pada umur 56 HST, namun berpengaruh tidak nyata terhadap tinggi tanaman dan diameter batang pada umur 14, 21, 28, 35, 42, 49 dan 56 HST, umur 
tanaman saat berbunga, umur panen, panjang buah, jumlah buah, berat buah per buah, berat buah per tanaman dan potensi hasil. Rata-rata pertumbuhan tanaman cabai merah perlakuan varietas dapat dilihat pada Tabel 3.

Penelitian ini menunjukkan bahwa varietas perpengaruh nyata pada peubah tinggi tanaman pada umur 56 HST. Pertumbuhan terbaik ditemukan pada varietas Laba dan Lado F1. Hal ini diduga karena varietas Laba dan Lado F1 memiliki sifat genetik, mempengaruhi pertumbuhan dan daya adaptasi suatu varietas dengan lingkungan sehingga mendapatkan hasil yang baik. Hal ini sejalan dengan penelitian Sepwanti et al (2016) bahwa tingginya hasil suatu varietas karena varietas tersebut telah mampu beradaptasi dengan lingkungannya. Jadi, secara genetik terdapat varietas yang mempengaruhi pertumbuhan tanaman, tapi hanya berhasil jika sudah berinteraksi dengan lingkungan yang tepat.

Tabel 3. Rata-rata tinggi tanaman dan diameter batang cabai akibat perlakuan varietas secara hidroponik substrat

\begin{tabular}{|c|c|c|c|c|c|}
\hline \multicolumn{2}{|c|}{ Parameter yang diamati } & \multicolumn{3}{|c|}{ Varietas } & \multirow[b]{2}{*}{$\mathrm{BNJ}_{0,05}$} \\
\hline & & $\mathrm{V}_{1}$ & $\mathrm{~V}_{2}$ & $\mathrm{~V}_{3}$ & \\
\hline \multirow{7}{*}{$\begin{array}{l}\text { Tinggi tanaman } \\
(\mathrm{cm})\end{array}$} & 14 HST & 8,79 & 10,04 & 10,53 & \\
\hline & $21 \mathrm{HST}$ & 11,40 & 13,74 & 14,53 & \\
\hline & 28 HST & 15,60 & 16,89 & 18,46 & \\
\hline & $35 \mathrm{HST}$ & 18,46 & 19,99 & 22,54 & \\
\hline & $42 \mathrm{HST}$ & 21,84 & 22,70 & 26,56 & \\
\hline & 49 HST & 25,11 & 26,67 & 29,61 & \\
\hline & $56 \mathrm{HST}$ & $30,30 \mathrm{a}$ & $35,43 \mathrm{ab}$ & $40,11 \mathrm{~b}$ & 7,55 \\
\hline \multirow{7}{*}{$\begin{array}{l}\text { Diameter batang } \\
(\mathrm{mm})\end{array}$} & 14 HST & 1,34 & 1,64 & 1,44 & \\
\hline & $21 \mathrm{HST}$ & 2,20 & 2,20 & 2,17 & \\
\hline & 28 HST & 2,34 & 2,38 & 2,40 & \\
\hline & 35 HST & 2,55 & 2,60 & 2,77 & \\
\hline & $42 \mathrm{HST}$ & 3,50 & 3,57 & 3,79 & \\
\hline & 49 HST & 4,37 & 4,56 & 4,75 & \\
\hline & $56 \mathrm{HST}$ & 4,95 & 5,05 & 5,35 & \\
\hline
\end{tabular}

Keterangan: Angka yang diikuti oleh huruf yang sama pada kolom yang sama berbeda tidak nyata pada taraf $5 \%$ (Uji BNJ 0.05$)$. 
Tabel 4. Rata-rata umur tanaman saat berbunga, umur panen, panjang buah, jumlah buah, berat buah per buah, berat buah per tanaman dan potensi hasil akibat perlakuan varietas secara hidroponik substrat

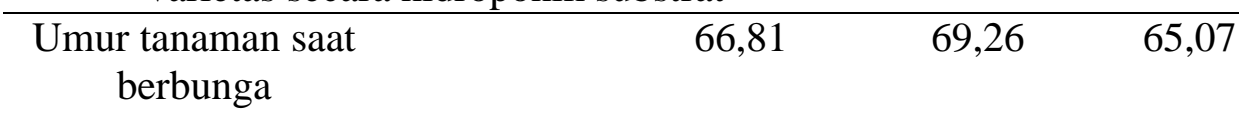

\begin{tabular}{cccc}
\hline Umur panen & 88,67 & 87,89 & 92,22 \\
\hline Panjang buah (cm) & 7,97 & 8,61 & 8,57 \\
\hline $\begin{array}{c}\text { Jumlah buah per } \\
\text { tanaman }\end{array}$ & 22,94 & 21,46 & 23,97 \\
\hline $\begin{array}{c}\text { Berat buah per buah } \\
\text { (g) }\end{array}$ & 3,28 & 3,38 & 3,43 \\
\hline $\begin{array}{c}\text { Berat buah per } \\
\text { tanaman }(\mathrm{g})\end{array}$ & 57,08 & 52,66 & 55,76 \\
\hline $\begin{array}{c}\text { Potensi hasil } \\
\left.\text { (ton ha }{ }^{-1}\right)\end{array}$ & 1,82 & 1,68 & 1,78 \\
\hline
\end{tabular}

Penelitian ini menunjukkan bahwa hasil terbaik dijumpai pada varietas Kencana. Menurut Ariesna et al. (2014) bahwa setiap varietas memiliki kemampuan berbeda-beda, membawa bahan genetiknya sendiri dan mempunyai tanggung jawab terhadap sintesis protein, enzim dan hormon dari varietas itu sendiri. Di dukung oleh penelitian Fitria et al. (2018) bahwa penyebab beragamnya suatu varietas dikarenakan adanya perbedaan susunan genetik. Dengan adanya susunan genetik tanaman pada suatu pertumbuhan akan berdampak pada sifat tanaman baik bentuk maupun fungsinya dalam menghasilkan keragaman pertumbuhan tanaman cabai merah.

Hasil cabai merah terndah dijumpai pada varietas Laba F1. Hal ini dikarenakan cabai merah tersebut terkena virus keriting pada daun karena adanya tanaman inang lainnya seperti pohon sawit dan pagi sehingga pengaruh lingkungan yang menyebabkan cabai merah varietas Laba F1 memiliki ukuran buah yang besar, jumlah buah yang sedikit dan produksi lebih rendah dibandingkan dengan varietas Lado F1 yang memiliki buah yang besar dan dalam jumlah yang terbatas. Hal ini didukung oleh Sitohang et al. (2014) bahwa banyaknya buah pada suatu varietas disebabkan karena pengguna benih yang memiliki produksi yang tinggi.

\section{Pengaruh Interaksi antara Perbedaan Jenis Media Tanam dan Varietas terhadap Pertumbuhan dan Hasil Tanaman Cabai Merah Secara Hidroponik Substrat}

Hasil penelitian menunjukkan bahwa interaksi antara jenis media tanam dan varietas berpengaruh tidak nyata terhadap semua peubah yang diteliti. Hal ini dikarenakan bahwa perbedaan pertumbuhan dan hasil tanaman cabai merah akibat perlakuan jenis media tanam yang berbeda, tidak tergantung pada varietas yang digunakan atau sebaliknya.

\section{KESIMPULAN DAN SARAN}

Hasil penelitian menunjukkan jika perlakuan jenis media tanam berpengaruh sangat nyata terhadap tinggi tanaman cabai merah pada umur 14, 21, 28, 35 dan 56 HST, diameter 
batang pada umur 21, 35, 42 dan 56 HST dan panjang buah serta berpengaruh nyata terhadap tinggi tanaman cabai merah pada umur 42 dan 49 HST, diameter batang pada umur 14 dan 28 HST dan berat buah per buah. Pertumbuhan tanaman+ cabai merah yang terbaik dijumpai pada perlakuan jenis media tanam petroganik + pasir. Perlakuan varietas berpengaruh nyata terhadap tinggi tanaman pada umur 56 HST. Tinggi tanaman cabai merah tertinggi dijumpai pada perlakuan varietas Kencana yang berbeda tidak nyata dengan varietas lainnya. Interaksi antara jenis media tanam dan varietas yang berpengaruh tidak nyata terhadap pertumbuhan dan hasil tanaman yang diamati. Saran untuk penelitian lanjutan mengenai jenis media tanam petroganik + arang sekam secara hidroponik substrat dengan perbandingan berdasarkan volume yang berbeda untuk mendapatkan pertumbuhan dan hasil cabai yang lebih baik.

\section{UCAPAN TERIMA KASIH}

Terima kasih kepada kak hadianur yang telah memberi izin memakai laboratorium hortikultura, ibu mardhiah dan ibu marai sebagai dosen pembimbing yang telah membimbing dan memberi masukan, bapak Trisda sebagai dosen wali yang telah memberi banyak masukan, ibu Elly Kesumawati sebagai dosen penguji yang telah memberikan masukan dan saran, kepada kak eva, Nadya Pohan, Zurlaily, Fitrah, Mutiara yang telah membantu dan mendukung kegiatan penelitian sampai selesai.

\section{DAFTAR PUSTAKA}

Ariesna, F.D., Sudiarso dan N. Herlina. 2014. Respon 3 varietas tanaman krisan (Chrysanthemum morifolium) pada berbagai warna cahaya tambahan. Jurnal Produksi Tanaman. 2(5): 419-426.

Cendana, S. 2016. Pengaruh takaran arang sekam padi dan frekuensi penyemprotan pupuk organik cair terhadap pertumbuhan dan hasil tanaman cabai merah (Capsicum annum L.) Jurnal Pertanian Konservasi Lahan Kering. 1(4): 125-127.

Fahmi, T dan E. Sujitno. 2011. Peningkatan Produksi Cabai Merah (Capsicum annum L.) Melalui Penggunaan Varietas Unggul di Kecamatan Sukamantri, Kabupaten Ciamis Provinsi Jawa Barat. Balai Pengkajian Teknologi Pertanian Jawa Barat, Bandung.

Fitria, E., E. Kesumawaty dan Bakhtiar. 2018. Pengaruh varietas dan pemberian berbagai dosis pelet Tricoderma harzianum terhadap produksi cabai (Capsicum annum L.). Jurnal Floratek. 13(1): 49-57.

Gustia, H. 2013. Pengaruh penambahan sekam pada media tanam terhadap pertumbuhan dan produksi tanaman Sawi ( Brasica juncea L.). E. Jurnal Widia Kesehatan dan Lingkungan. 1(1): 12-17.

Hijrah, A. Ramadhan dan D. Tureni. 2017. Pengaruh pemberian pupuk organik super pertoganik terhadap pertumbuhan ikan bandeng (Chanos) di Desa Dolago Kecamatan. Parigi selatan Kabupaten. Parigi moutong dan perkembangannya sebagai pembelajaran media biologi. E-JIP BIOL. 5(2): 41-59. 
Indrawati, R., D. Indradewa dan S. N. H. Utami. 2012. Pengaruh komposisi media dan kadar nutrisi hidroponik terhadap pertumbuhan dan hasil tomat (Lycopersicum esculentum Mill.). Vegetalika. 1(3): 109-119.

Istiqamah, S. 2006. Menanam Hidroponik. Azka Press, Jakarta.

Isworo, D. 2018. Kajian media hidroponik dari campuran bahan baku limbah baglog dan arang sekam. Skripsi. Jurusan Teknik Pertanian. Fakultas Pertanian. Universitas Lampung, Bandar Lampung.

Kementerian Pertanian Republik Indonesia. 2018. Statistik Pertanian. Pusat Data dan Sistem Informasi Pertanian Kementerian Pertanian Republik Indonesia, Jakarta.

Onggo, T. M. A. Kusumiyati. dan Nurfitriana. 2017. Pengaruh penambahan arang sekam dan ukuran polybag terhadap pertumbuhan dan hasil tanaman tomat kultivar (Valouro) hasil sambung batang. Jurnal Kultivasi. 16(1): 299-304.

Prakosa, M. 2000. Informasi Pelepasan Cabai Keriting Varietas Lado F1. https://peraturan.bkpm.go.id/jdih/userfiles/batang/KepMenTan 138 2000. 4 Maret 2019.

Perwitasari, B., Tripatmasari, Mustika dan C. Wisonowati. 2012. Pengaruh media tanam dan nutrisi terhadap pertumbuhan dan hasil tanaman pakcoy (Brassica juncea L.) dengan sistem hidroponik. J. Agrovigor. 5(1): 14-24.

Purnomo, J., D. Harjoko dan T. D. Sulistyo. 2016. Budidaya cabai rawit (Capsicum frutescens L.) dalam sistem hidroponik substrat dengan variasi media dan nutrisi. Journal of Sustainable Agriculture. 31(2): 129-136.

Putra, H, D., D. Harjoko dan H. Widijanto. 2013. Penggunaan pasir dan serat kayu aren sebagai media tanam terong dan tomat dengan sistem hidroponik. Jurnal Agrosains. 15(2): $10-14$.

Rindani, M. 2015. Kesesuaian lahan tanaman cabai merah di lahan jorong kota Kenagarian Lubuak Batingkok, Kecamatan. Harau, Kabupaten. Lima Puluh Kot Payakumbuh. Nasional Ecopedon. 2(2): 28-33.

Sepwanti, C., M. Rahmawati dan E. Kesumawati. 2016. Pengaruh varietas dan dosis kompos yang diperkaya Tricoderma harzianum terhadap pertumbuhan dan hasil tanaman cabai merah (Capsicum annum L.). Jurnal Kawista Agroteknologi. 1(1): 68-74.

Siswandi. 2006. Tanaman Hidroponik. PT Citra Aji Parama, Yogyakarta.

Siswanto, B. dan Widowati. 2017. Pengaruh pemberian pupuk petroganik dan kompos pada vertisol bekas galian pembuatan batu bata terhadap serapan $\mathrm{N}$ serta pertumbuhan tanaman jagung. Buana Sains. 17(1): 96-102. 
Subandi, M., N. P. Salam dan B. Frasetya. 2015. Pengaruh berbagai nilai EC (Electrical Conductivity) terhadap pertumbuhan dan hasil bayam (Amaranthus sp.) pada hidroponik rakit apung (floting hidroponik system). Jurnal Agroteknos. 4(2): 137151.

Sulistio, A. H. Sutejo dan M. Napitupulu. 2018. Pengaruh pupuk petroganik dan pupuk growmore terhadap pertumbuhan dan hasil tanaman cabai rawit (Capsicum frutencens L.) varietas dewata 42 f1. Jurnal Agrifor. 17(1): 30-40.

Sutrisni, A. 2016. Uji aktivitas senyawa bioaktif kapang (gliocladium sp) terhadap fusarium oxysporum, capsici penyebab layu pada tanaman cabai secara in-vitro. Bachelor Thesis. Universitas Muhammadiah Purwokerto, Jawa Tengah.

Suwardani, N. W. Purnomowati dan E. T. Sucianto. 2014. Kajian penyakit yang disebabkan oleh cendawan pada tanaman cabai merah (Capsicum annuum L.) di pertanaman rakyat Kabupaten Brebes. Jurnal Scripta Biologica. 1(3): 223-225. 